Collins, V. G. (1957). J. gen. Microbiol. 16, 268-272

\title{
Planktonic Bacteria
}

\author{
BY VERA G. COLLINS \\ Freshrwater Biological Association, Ferry House, Far Sawrey, Ambleside, Westmorland
}

From the Chambers's Technical Dictionary the definition of 'Plankton' is as follows: 'Animals and plants floating in the waters of the seas, rivers, ponds, and lakes, as distinct from animals which are attached to, or crawl upon, the bottom; especially minute organisms and forms, possessing weak locomotor powers.' The broader aspects of the activities of bacteria in lake water in relation to the establishment of the conditions which determine their growth and their relationship with other forms of plankton has been the primary object of current work in the bacteriology department of the Freshwater Biological Association. Before considering the results on the distribution of bacteria it is important to consider the physical conditions which occur in lakes, in view of the probable effect of those conditions on the bacteria. During the late spring and early summer the temperature of the surface water of a lake rises owing to increased solar radiation, the resulting difference in density of the water gives rise to the formation of two distinct layers of water, the upper layer or 'epilimnion' and the lower layer or 'hypolimnion'. Under some conditions the temperature is approximately the same at all depths in the epilimnion; below this layer, in the transitional zone known as the 'thermocline', the temperature falls rapidly with increasing depth; and in the hypolimnion the temperature, which is considerably lower than that of the epilimnion, does not change appreciably with increasing depth. Under some conditions the temperature in the upper layer falls rapidly with increasing depth from the surface to the thermocline. During the winter months the stratification of the water in Windermere is destroyed by the cooling of the upper layer or by the circulatory motion set up by the action of strong winds across the surface of the lake. In Windermere this mixing may take some weeks, but in the more shallow lakes, e.g. Esthwaite the 'overturn' of the waters may take place during the first autumnal gale.

It is apparent that following the period when the temperature is uniform throughout the lake, the effect of warmer external conditions is to warm the water at all depths but decreasingly so at increasing depths. As circulation of the water gradually ceases, a time is reached when the temperature at the bottom remains constant to within a fraction of a degree and stratification is then established. The nature of the thermocline and the depth at which it occurs vary greatly, but in general the depth tends to increase as the summer advances and the ratio of the volume of epilimnion to volume of hypolimnion therefore increases.

When the layering has begun, the amount of dissolved oxygen becomes gradually less in the hypolimnion owing to the stagnation of the water and the increased activity of the bacterial population of the mud surface. The dissolved oxygen continues to be present in normal amounts in the circulating waters of 
the epilimnion. The concentration of dissolved oxygen in the lakes under investigation appears to be related to depth, shallow lakes being depleted to a greater extent because of the increased surface area of the mud exposed to the overlying water, than in the case of lakes with greater depth. The nearer the bottom, i.e. the interface between mud and water, the greater is the depletion.

Rainfall is another important factor to be considered in relation to the bacteriology of water. Rain falling on the drainage basin surrounding a lake is the carrier of the material brought into the lake by inflowing rivers. These inflowing rivers can also affect the temperature gradient of the water profile of a lake, the temperature of the inflowing river determining the position of the flow-in of water, warm river water going to the surface layers of the lake, and cooler river water sinking to lower layers. This was clearly shown in 1955 in Windermere. During a period of very calm dry weather, a heavy rainstorm struck the district and the result was for the river water to slide in under the surface waters, giving high numbers of bacteria at various depths in the water column. The extent and direction of wind force plays a very large part in determining bacterial distribution because of the water movements created in the surface layers of large bodies of water, and even more so in shallow lakes where the deeper layers can be disturbed in midsummer thus creating an artificial overturn condition for brief periods.

In general one may conclude, having regard to the above-mentioned physical conditions, that the bacteria present at any time in the water of a lake may be considered in three categories: $(a)$ those washed in from outside sources, of which a large proportion will ultimately perish and others which may find conditions suitable for growth; $(b)$ indigenous bacteria capable of existence in a dilute nutrient solution, as represented by lake water, and able to use for growth low concentrations of available organic matter; $(c)$ bacteria dependent on a solid surface for their proliferation and therefore found in connexion with soil particles, mud detritus and plankton. This group may be further divided into types with special hold-fast mechanisms such as stalks and which are found only under natural conditions, and others which adhere to surfaces by mucilaginous material, the types which grow on the sides of containers.

Work over the past few years has involved the routine weekly sampling of two lakes in the English Lake District, namely Windermere and Esthwaite, and also monthly samples from the surface waters of every lake in the English Lake District. The results present a composite picture of the numbers and types of bacteria in these lake waters throughout the seasons.

Several hundred cultures of bacteria were isolated from samples of water plated out on standard agar (Taylor, 1940), in the above work. In view of past experience no attempt was made to classify them by the usual biochemical methods; instead a routine study was made of their ability to grow in media containing either inorganic or organic nitrogen, and different carbon sources.

Since the complex chemical constitution of natural waters makes them unsuitable for studies on the essential substances required for bacterial growth it was decided to use distilled water as a base and to control the composition 
of the medium by the addition of known amounts of pure chemicals. The principle used was to prepare large amounts of distilled water inoculated with lake water and to add to the bulk known quantities of mineral salts, nitrogen and phosphorous sources, and a carbon and energy source. In various experiments one or more constituents was omitted or the quantity added in different concentrations. Bottles ( $8 \mathrm{oz}$.) were filled with the 'water medium' and the activity of the bacteria measured by determining the amount of oxygen consumed after periods of incubation at $20^{\circ}$. In further experiments lake water was used as a base and the effect of the addition of nitrogen, phosphorus and available organic matter was determined by the same method.

Although the work is by no means complete, and further experiments are required to clarify effects due to seasonal changes in the phytoplankton and chemical composition of the lake water, it is believed that a general picture of the bacteriology of lake water can be drawn as follows. Normally the growth of bacteria in lake waters is limited by the availability of the supply of carbon and energy sources. During long rainless periods the plate counts of bacteria decrease steadily and only increase after rain. This increase is partly due to washed-in bacteria but also to multiplication of types which avail themselves of the washed-in organic matter. The water acts as a selective agent in determining the types of washed-in soil bacteria which survive in this medium; some of the most common soil bacteria are absent. Factors which affect the selection of different types of bacteria include the concentration of dissolved substances, particularly phosphorus, the availability of organic nitrogen for types which are unable to use inorganic nitrogen, the presence or absence of particulate matter necessary for certain types of bacteria which require a site for attachment.

A large proportion of the types of bacteria in water have very weak powers of resistance and are difficult or impossible to maintain on laboratory media. All types which survived isolation from plates of standard agar grew in a liquid medium containing peptone; a proportion of these grew in a defined medium containing ammonium salts, and a small proportion when nitrate was the nitrogen source. No culture was obtained which used nitrate but not ammonia. More cultures grew in defined media containing nitrate or ammonia when a low concentration of agar was added than in its absence, due, it is believed, more to the growth-promoting activity of the agar (? source of growth factor) than to the availability of a semi-solid surface. Bacteria isolated after rain were more active physiologically, in respect to the use of ammonia and nitrate, than those isolated before rain. Plate counts on differential media after heavy rain usually showed a much larger relative increase in bacteria which required organic nitrogen rather than inorganic.

Experiments with a distilled water base medium showed that a readily available carbon and energy source, e.g. glucose, was rapidly decomposed by a mixed flora of lake bacteria when inorganic nitrogen and phosphate were added in the absence of all cations other than the traces present as impurities in the chemicals. Sodium and magnesium did not increase bacterial activity but calcium and magnesium or a mixture of all four ions did, phosphates of 
sodium and calcium were equally effective. When nitrogen and available organic matter were in excess of requirements the amount of the latter which was decomposed at any time was a function of the concentration of the available phosphate. Phosphate in lake waters is slowly regenerated and the added organic matter similarly decomposed, but the addition of phosphate markedly hastens the process. Response to amounts of phosphorus as low as $1 \mu \mathrm{g} . / 1$. can readily be detected. The most important finding was that the addition of small amounts of iron (as $\mathrm{FeCl}_{3}$ ) immobilized phosphate for bacterial use. A concentration of $0.5 \mathrm{mg}$. Fe/l. was sufficient to prevent any decomposition of glucose in the presence of $8 \mu \mathrm{g}$. $\mathrm{P} / \mathrm{l}$. during incubation for 4 days; even onetenth of this amount was sufficient to depress the activity by a half.

The application of this technique to lake waters shows that nitrogen is usually present in excess of requirements and that phosphate is either regenerated or sufficiently slowly available to bring about eventually the decomposition of added glucose. However, when waters from different lakes were treated with small amounts of phosphate and excess glucose, the amount of glucose decomposed (measured by the oxygen consumed) was appreciably different and in all instances appreciably lower than in a simple 'artificial water' based on distilled water. It is concluded that this phenomenon is similar to that which occurs in agricultural soils and that part of the added phosphorus becomes unavailable. There appears to be little doubt that the concentration of iron in natural waters plays an important part in phosphorus immobilization.

\section{Relationships between bacteria and other planktonic organisms in water}

In view of the neglected state of research on fundamental problems of the bacteriology of waters, it is not surprising that little is known about the association of bacteria with planktonic animals and plants. Some simple relationships between bacteria and algae have been established, but more intricate problems, particularly those concerning stimulation or repression of one or the other by means of products excreted from the organisms, remain to be investigated. The production of complex organic compounds by algae in waters otherwise deficient in available energy and carbon sources for bacterial growth must be a factor in establishing the population of bacteria in water. On the other hand, bacteria can decompose organic matter and release available nutrients for algal growth. Whilst it has been established that in the sea and in lakes a large population of bacteria is associated with phytoplankton there is no evidence to show that bacteria are capable of attacking living diatoms. The excretion of organic compounds and antibiotics by living algae has been suggested by different workers. Present knowledge on the association of bacteria and the zooplankton seems too limited to the consumption, often on a selective basis, of bacteria by particle-feeding animals, and to decomposition of dead animals by bacteria.

The numbers of bacteria in different samples of phytoplankton is very variable. The bacteria are almost entirely rods or coccoid-rods and appear in localized concentrations. Such are seen sometimes in or on the mucilaginous 
capsule of some blue green algae, or unattached. Examination of Asterionella shows the presence of a bacterium similar to Caulobacter species attached by a stalk to the cell wall of the diatom. Although the moribund diatoms are observed to have this type of bacterium attached, there is no significant increase in plate counts of bacteria following the death of these diatoms in lake water. No appreciable increase in available organic matter can be detected by the biochemical oxygen demand test in waters which have developed very large growth of Asterionella. There is, however, a marked increase in the numbers of bacteria in lake water on the death of large populations of bluegreen algae, the biochemical oxygen demand increasing considerably as compared with the value for the same lake water without blue-green algae. Certain protozoans epizoic on flatworms form vacuoles whose internal contents contain bacterial rods like those present in water. These are clearly demonstrated by use of the phase contrast microscope. The existence of symbiotic relationships between bacteria and plankton, under natural conditions, remains to be established.

\section{REFERENCE}

TAYLOR, C. B. (1940). Bacteriology of fresh water. I. Distribution of bacteria in English lakes. J. Hyg., Camb. 40, 616. 